\title{
Influence of salt in the tectonic development of the frontal thrust belt of the eastern Cordillera (Guatiquía area, Colombian Andes)
}

\author{
Vanessa Parravano ${ }^{1}$, Antonio Teixell ${ }^{2}$, and Andrés Mora ${ }^{3}$
}

\begin{abstract}
Geologic maps, seismic lines, and data from a dry exploration well were used to develop a new structural model for a segment of the eastern foothills of the Eastern Cordillera of Colombia, emphasizing the role of salt tectonics. Milestones in the deformation history of the Guatiquía foothills were studied by sequential section restoration to selected steps. Uncommon structural geometries and sparse salt occurrences were interpreted in terms of a kinematic evolution in which Cretaceous salt migration in extension produced a diapiric salt wall, which was subsequently welded during the main episodes of the Andean compression, when the salt wall was squeezed generating a large overturned flap. Salt-weld strain hardening resulted in breakthrough thrusting across the overturned flap in late deformation stages. We have evaluated a pattern of salt tectonics previously unrecognized in the foothills thrust belt, which may be significant in other parts of the external Colombian Andes.
\end{abstract}

\section{Introduction}

The prolific thrust belt of the eastern foothills of the Eastern Cordillera (EC) of Colombia has been intensively investigated since the discovery of the Cusiana giant oil field in 1992. Diverse authors have illustrated via structural cross sections, and kinematic restoration models the foothills structure as consisting of an eastverging thrust system with imbricate fans and duplexes, conforming to ramp-flat geometries (Dengo and Covey, 1993; Cazier et al., 1995; Cooper et al., 1995; Rowan and Linares, 2000; Toro et al., 2004; Martinez, 2006; Mora et al., 2006, 2010, 2013; Tesón et al., 2013; Teixell et al., 2015). These works emphasize tectonic inversion of former extensional faults, giving rise to either basementinvolved or thin-skinned thrusts.

Within the south-central part of the eastern foothills, the Guatiquía area (Figure 1) shows features that differ from the more standard ramp-flat, fault-related folding reported for other segments of the thrust belt. A large overturned panel of Cretaceous rocks is exposed in the frontal thrust sheet and was crossed by the Anaconda-1 exploration well. The well targeted a subthrust play with fault-bend antiformal culminations comparable to Cusiana, which was not encountered. Rather, the footwall of the emergent Mirador thrust comprised the inverted limb of a complex syncline (Kammer et al., 2005; Mora et al., 2008).
We aim to provide an explanation for differences in structural style in the EC external thrust belt. Based on seismic lines, maps, the occurrences of salt in old mines, and a detailed analysis of the postdrilling information from the Anaconda-1 well, we propose a new kinematic model for the Guatiquía segment, which emphasizes the influence of long-lived salt tectonics, especially during early deformation stages (Cretaceous extension and early Cenozoic contraction), which has been masked by the later stages of the Andean compression. The model accounts for early layer tilting, diapir squeezing, and the formation of an overturned flap, with similarities to other remarkable recumbent folds in thrust settings recently interpreted as salt related (e.g., Graham et al., 2012; Rowan et al., 2014), and it bears implications for other compressional areas in which the role of salt can be overlooked due to diapir welding and/ or dissolution.

\section{Geologic setting}

The EC is the easternmost branch of the northern Andes of Colombia (Figure 1). It is a 110-200-km-wide intracontinental mountain belt related to transmission of stresses to the South American plate by the accretion of arcs in the northwestern Andes and appears as a doubly verging thrust system that formed during the Ceno-

\footnotetext{
${ }^{1}$ Formerly Universitat Autònoma de Barcelona, Departament de Geologia, Barcelona, Spain; presently SGS Horizon, Voorburg, The Netherlands. E-mail: parravanov@gmail.com.

${ }^{2}$ Universitat Autònoma de Barcelona, Departament de Geologia, Barcelona, Spain. E-mail: antonio.teixell@uab.es.

${ }^{3}$ Instituto Colombiano del Petróleo-Ecopetrol, Bucaramanga, Colombia. E-mail: andresmora30@googlemail.com.

Manuscript received by the Editor 15 January 2015; revised manuscript received 26 March 2015; published online 24 July 2015 . This paper appears in Interpretation, Vol. 3, No. 4 (November 2015); p. SAA17-SAA27, 7 FIGS.

http://dx.doi.org/10.1190/INT-2015-0011.1. @ 2015 Society of Exploration Geophysicists and American Association of Petroleum Geologists. All rights reserved.
} 
zoic by the inversion of a Mesozoic back-arc rift (Colletta et al., 1990; Cooper et al., 1995).

The rifting history of the EC had a main phase during the early Cretaceous when a graben system approximately coincident with the present Cordillera formed (Etayo et al., 1969; Cooper et al., 1995; Sarmiento-Rojas, 2001). Cretaceous sediments (up to 8-10 km thick) are dominantly marine. Terrestrial deposits indicative of an overfilled basin appear in the late Maastrichtian-Paleocene. Uplift of the EC was associated with a progressive emersion of the former rift due to tectonic inversion and with subsidence in the adjacent foreland basins such as the Llanos basin in the eastern side (Figure 1).

The study area is located in the eastern foothills of the EC between the Guatiquía and Guamal rivers (Figure 1), in which the thrust belt overrides the Llanos basin and is associated with a topographic increase from 400 to $1700 \mathrm{~m}$ above sea level (asl).

\section{Tectonostratigraphic evolution}

The stratigraphy of the study area is sketched in Figure 2. We refer the reader to Renzoni (1968), Etayo et al. (1969), Mora et al. (2006), and Mora and Parra (2008) for detailed references. Basement, which crops out in the Quetame massif and in the Mirador thrust hanging wall (Figure 1), consists of lower Paleozoic metamorphic rocks (Quetame Group), and the overlying DevonianCarboniferous Farallones Group, that accumulated in extensional grabens (Mora et al., 2006).

The Mesozoic synrift sequences start with the Buenavista breccia, which contains Tithonian-Berriasian ammonite fauna (Dorado, 1990). In the outcrop, the breccia often passes gradually upward into black shale forming the thick Macanal Formation and subsequent sandstone-shale formations (Figure 2). In between, early Berriasian evaporitic layers (halite, gypsum) were locally deposited (Hubach, 1957), which are now very

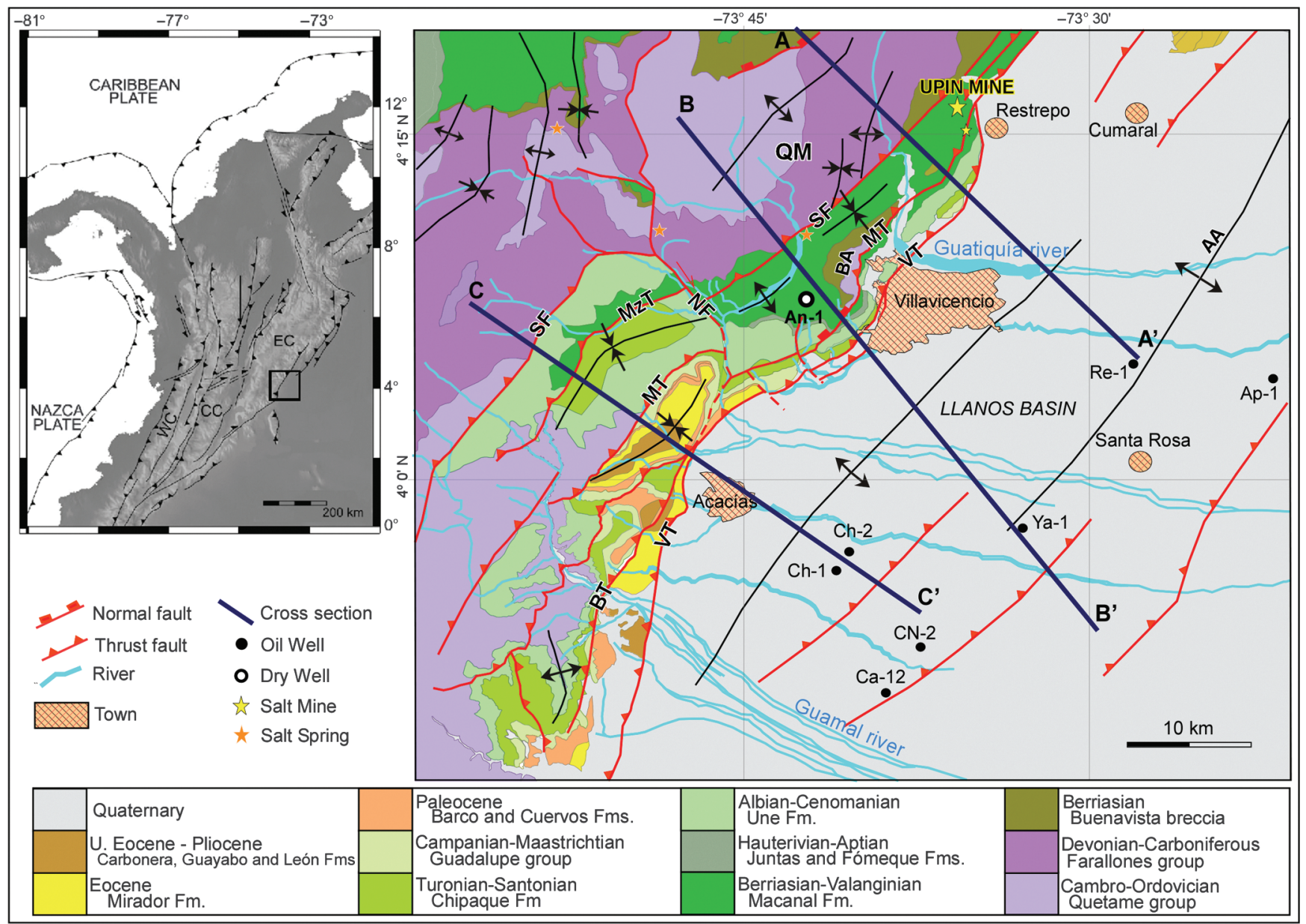

Figure 1. Geologic map of the Guatiquía-Guamal segment of the eastern foothills of the EC of Colombia, showing the principal faults, the Anaconda well, the main oil fields and the interpreted cross sections of (location map inset to the left; WC, western Cordillera; CC, central Cordillera; and EC). The map was constructed on the basis of published maps by Mora et al. (2006, 2013) and Mora and Parra (2008), locally supplemented by the INGEOMINAS 1:100,000 national map (Pulido et al., 1998). AA, Apiay anticline; BA, Buenavista anticline; BT, Boa thrust; MT, Mirador thrust; MzT, Manzanares thrust; NF, Naranjal fault; QM, Quetame massif; SF, Servitá fault; VT, Villavicencio thrust. Well names: An-1, Anaconda-1; Ap-1, Apiay-1; Ca-12, Castilla-12; CN-2, Castilla Norte-12; Ch-1, Chichimene-1; Ch-2, Chichimene-2; Re-1, Reforma-1; and Ya-1, Yacare-1. 
restricted in outcrop (e.g., in the Upín salt mine and La Campana salt layers west of Restrepo, Figure 1, and the emerald-bearing evaporitic layers of Chivor, Gachala and El Toro; Cheilletz and Giuliani, 1996; Branquet et al., 2002; Mora et al., 2009).

The early Cretaceous depositional settings were highly variable and disparate over short distances, due to extensional tectonism (Mora et al., 2006, 2009). In paleogeographic reconstructions (e.g., Sarmiento-Rojas et al., 2006), the early Cretaceous graben does not reach the southernmost part of the EC foothills, being limited by the Naranjal transfer paleofault, south of which the Albian overlies directly the Paleozoic (Figure 1). During the Albian-Late Cretaceous, the basin became dominated by thermal subsidence, with laterally expansive

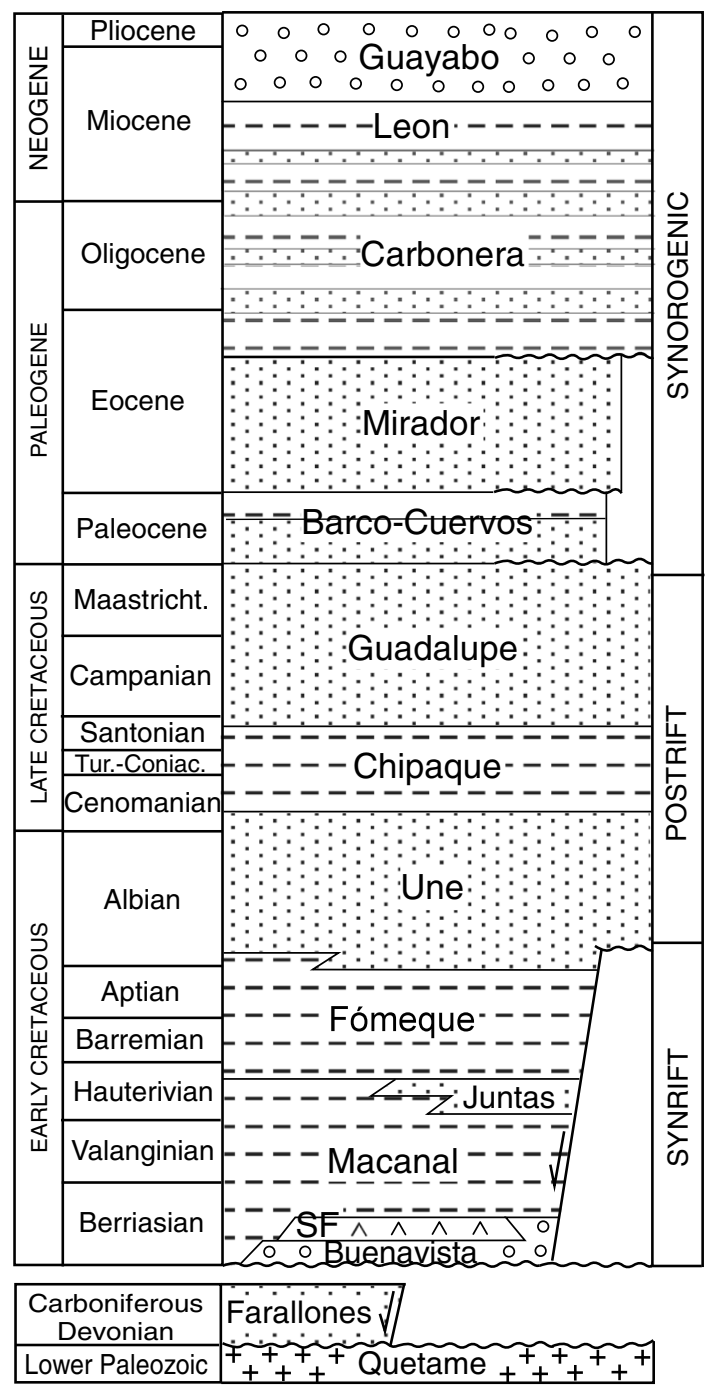

Figure 2. Simplified stratigraphy of the eastern flank of the EC in the Guatiquía-Guamal region (based on Toro et al., 2004; Mora et al., 2006; Parra et al., 2009b). SF, Salt formation; open circles, conglomerate and breccia; dashed pattern, shale and siltstone; dotted pattern, sandstone; crosses, crystalline basement. deltaic sandstones and deeper water shales (Une, Chipaque, and Gualdalupe Formations; Figure 2).

Toward the end of the Cretaceous, the EC became part of a large basin in front of the Central Cordillera, disrupted by growing folds that controlled the deposition of fluvial to transitional Paleogene units (Gomez et al., 2005) (Figure 2). The foreland basin megasequence in the eastern foothills and Llanos basin started in the mid-late Oligocene, as indicated by subsidence, exhumation, and provenance analysis in the fluvial Carbonera Formation (Parra et al., 2009a, 2009b; Horton et al., 2010). Coarse clastic influx by mid-Miocene times of the Guayabo conglomerate into the Llanos basin records the "Andean" main growth of the EC (Cooper et al., 1995; Hoorn et al., 1995; Branquet et al., 2002; Toro et al., 2004), continuing until recent times as recorded by synsedimentary deformation and very young apatite fission track ages (Mora et al., 2008).

\section{Data and methods}

Geologic maps available included the national quadrangle at 1:100,000 scale (Pulido et al., 1998) and those in Mora et al. (2006, 2013) and Mora and Parra (2008). Based on these maps and our own structural data, we generate a new map synthesis presented in Figure 1. We analyzed $1271 \mathrm{~km}$ of seismic profiles across the area provided by ICP-Ecopetrol. Synthetic seismograms of the Anaconda-1 well were generated for seismic-well calibration. In addition, the formational tops and data from the Anaconda well (Figure 3) were used to constrain the cross sections.

The seismic quality in the foothills is typically poor; stratigraphic horizons are irregularly imaged, but fault planes are often well imaged, suggesting distinctive rocks formed or injected along the fault zones. In the Llanos basin, reflectors are continuous and gently dipping (Figure 4). Structural transects were constructed with the goal to illustrate the lateral structural variation and using the maximum available surface and subsurface data (Figure 5). Time-depth conversions used replacement velocity of the seismic surveys and were calibrated with the Anaconda-1 well. Cross-section $\mathrm{BB}^{\prime}$ (Figure 1) is the most representative and was modeled by kinematic restoration in sequential steps, honoring available thermochronological data (Mora et al., 2008; Jimenez et al., 2013).

\section{Structural elements of the foothills in the Guatiquia and Guamal areas}

The innermost element of the area is the Quetame massif, a prominent basement uplift that is bounded by the Servitá fault (Figure 1 and 5). In front of it, the foothills can be divided into two segments by the Naranjal transfer fault (Figure 1). North of this fault (Guatiquía area), the Cretaceous displays an antiformal structure (Buenavista anticline) cut by the northwestdipping Mirador thrust along its core, which separates a normal limb region with gentle folds and a basement exposure from a large overturned limb that forms the 
mountain front (Kammer et al., 2005; Mora et al., 2006, 2008). The Anaconda-1 well indicated the existence of several splays of the Mirador thrust segmenting the footwall overturned panel (Figures 3 and 5). South of the Naranjal fault (Guamal area), the structure consists of a system of open folds related to imbricate thrusts (Toro et al., 2004; Mora and Parra, 2008; Mora et al., 2010). The Llanos basin is less deformed except in the vicinity of the mountain front, and a tabular late Cretaceous to Neogene succession is cut by blind thrusts and relict normal faults visible on seismic data (Figure 4b). The thrusts that are basement involved and steeply dipping, and in the case of the Chichimene oil field (Figure 1), demonstrably derive from the inversion of previous extensional faults (Kluth et al., 1997).

\section{Evidence for salt tectonics}

The long overturned limb of the Guatiquía foothills suggests folding mechanisms that differ from simple fault-bend folding. The northern end of the Buenavista anticline is the locus of the Upín and La Campana salt mines, which have produced since the sixteenth century. The salt deposits of these mines are found within the earliest Cretaceous shales (Wokittel, 1960). In the Upín
Figure 3. Stratigraphic column of the Anaconda-1 well, constructed on the basis of the well reports (Chevron Petroleum co. of Colombia, 1996, Anaconda-1 — Final Geological Report; Morales, P. S., Dueñas, H., and R. E. Navarrete, 1996, Biostratigraphic study - Anaconda-1 well section, Llanos foothills, Colombia: Bioss Ltda., Bioss Report 372/96) (see location in Figure 1). The major fault zone at $2415 \mathrm{~m}$ brings basement on top of Cretaceous and splays upsection into the Mirador and Villavicencio thrusts (Figure 5). $\mathrm{F}$, fault contact observed during well drilling; IF, inferred fault contact; N/S, no sample available.

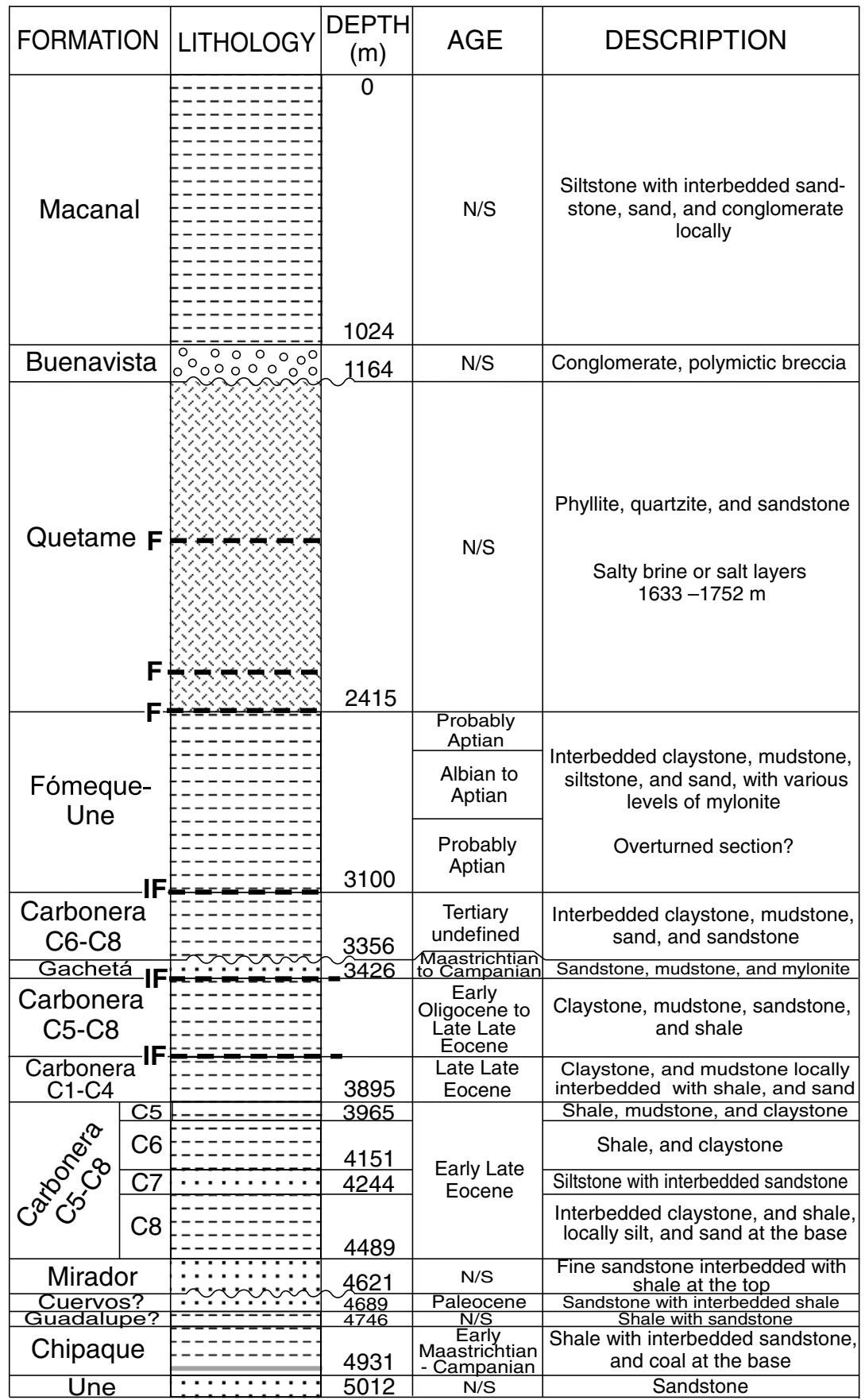


mine, salt has a stratiform pattern consisting of alternating slightly argillaceous and highly argillaceous halite layers (McLaughlin, 1972). Salt layers are disturbed, with variable attitude from moderately to steeply dipping, in response to regional tectonism and possibly diapirism (McLaughlin, 1972).

The fact that neither overturned Buenavista breccia nor basement is found in the surface or the subsurface is consistent with a detachment level for the overturned panel coinciding in stratigraphic position with the evaporites of the salt mines. On the other hand, numerous salt springs are found in the region (e.g., Salinas de $\mathrm{Cu}$ maral, $20 \mathrm{~km}$ north of Villavicencio).
In the Guateque-Medina area, north of the study area, a brecciated evaporitic layer below the Macanal Formation hosts emeralds and gypsum deposits (Figure 6) (Cheilletz and Giuliani, 1996; Branquet et al., 2002), in which fluid-inclusion studies revealed $\mathrm{Na}$-Ca-K-bearing hypersaline chlorine brines responsible for emerald and pyrite crystallization by deep-seated formation waters heated by burial, thereafter dissolving evaporites by interaction with salt diapirs (Giuliani et al., 1995).

The Anaconda-1 well reported high concentrations of chlorides in the mud system at a fault zone above the Villavicencio-Mirador thrust (see Figure 3), attributed to salty water of crystalline salt (Chevron Petroleum

\section{a) Line CHVRB-1993-105}
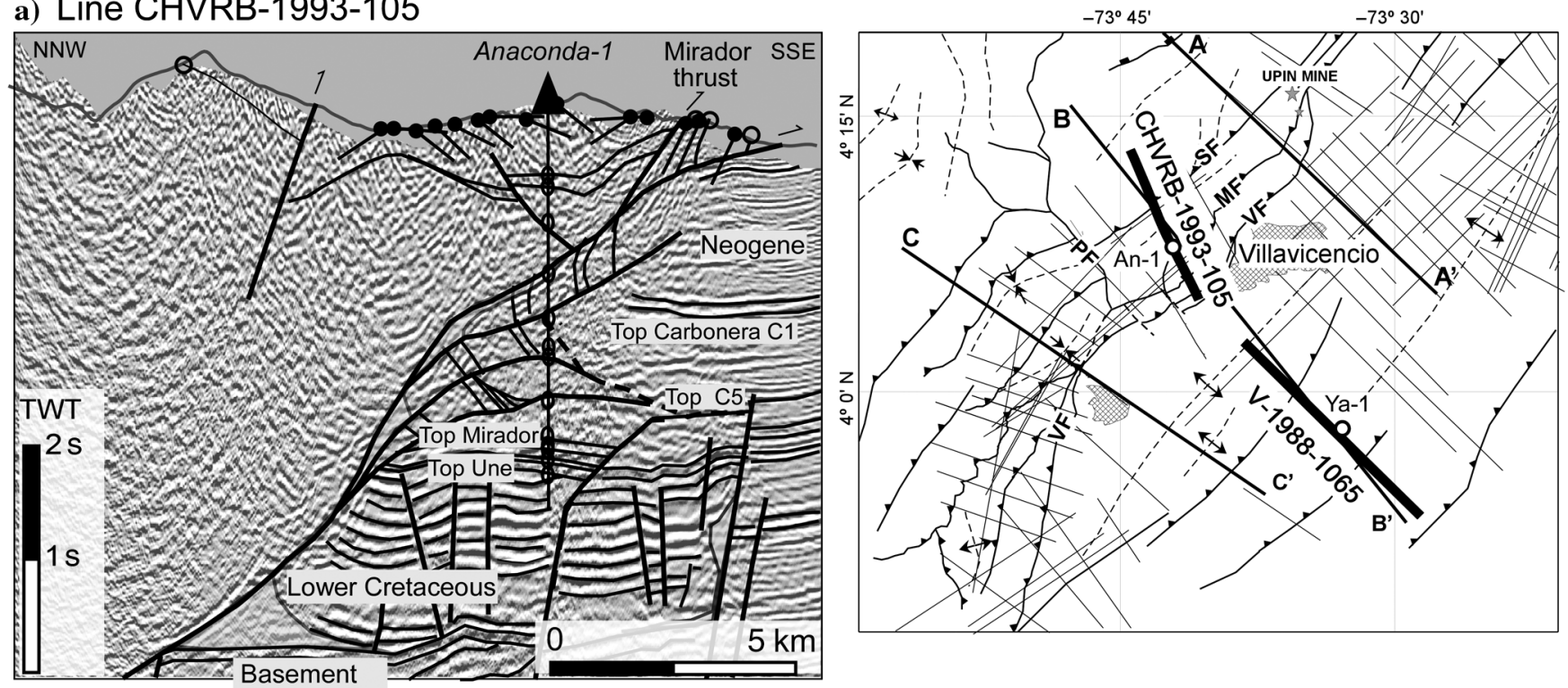

b) LineV-1988-1065

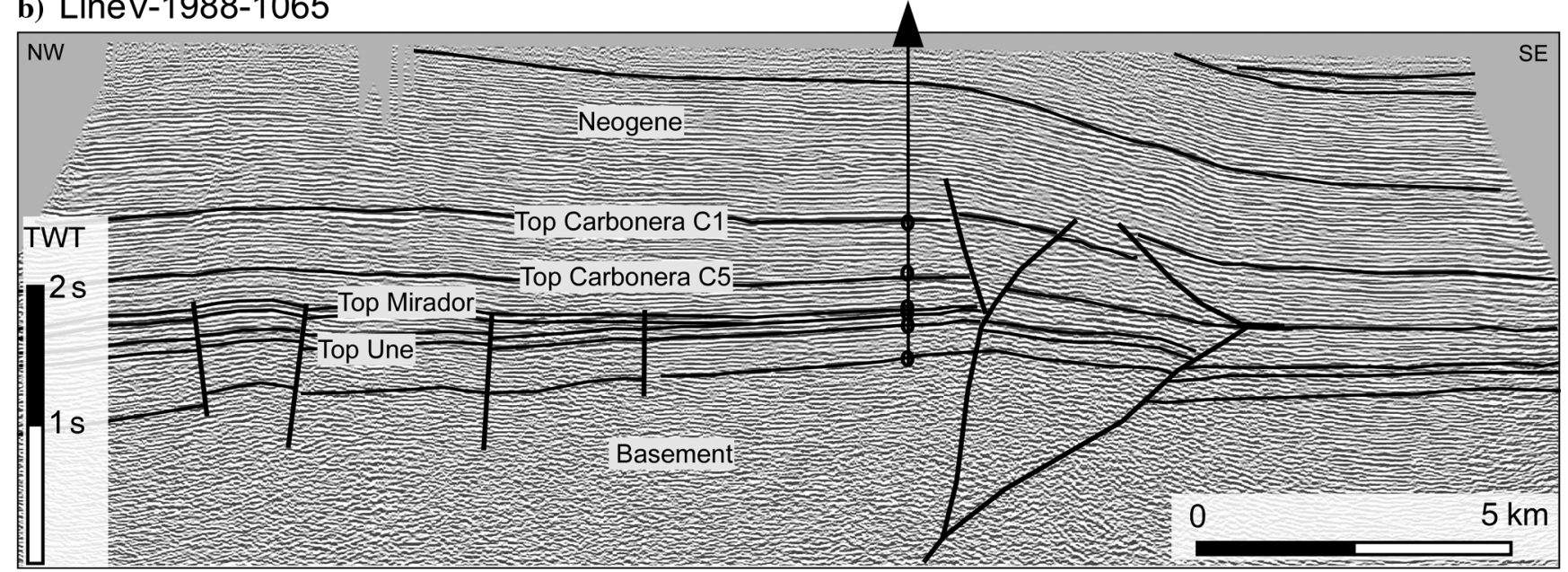

Figure 4. Selected seismic profiles for cross section B-B' (Figures 1 and 5). (a) Interpreted seismic line CHVRB-1993-105, with continuous reflections characterizing the basin, chaotic reflections in the foothills, and high-amplitude reflections for the deep Villavicencio-Mirador fault plane and minor faults above (b) Interpreted seismic line V-1988-1065 from the Llanos basin, showing very continuous and subhorizontal reflectors. In general, the sedimentary sequence thins to the east, although a more detailed interpretation shows that some late Cretaceous-early Paleogene reflectors onlap underlying ones and are restricted to the proximal foredeep. In the distal foredeep, the molasse sediments are folded over blind thrusts that affect the Cretaceous-Paleogene succession. 
co. of Colombia, 1996, Anaconda-1 - Final Geological Report). In the light of this, high reflectivity of fault zones in seismic profiles may be due to their content of salt. It is noteworthy that the southern end of the overturned panel coincides with the limit of the Lower Cretaceous basin at the Naranjal transfer fault, which reinforces its stratigraphic control, likely the occurrence of the early Cretaceous evaporitic formation.

We thus interpret that the association of an overturned panel and salt in the Buenavista anticline area is not accidental but indicative of a causal relationship. Strongly overturned fold limbs associated to salt diapir squeezing have been reported elsewhere (Graham et al., 2012; Rowan et al., 2014). Salt tectonic influences have never been reported in the foothills of the EC, but doubly verging folds and systematic limb overturning in the Sabana de Bogotá have been recently associated by Teixell et al. (2015) with salt-related detachment folding preceded by early diapirism of Cretaceous salt. Explanations for the association of thrust ramps and asymmetric

a) $\mathrm{NW}$
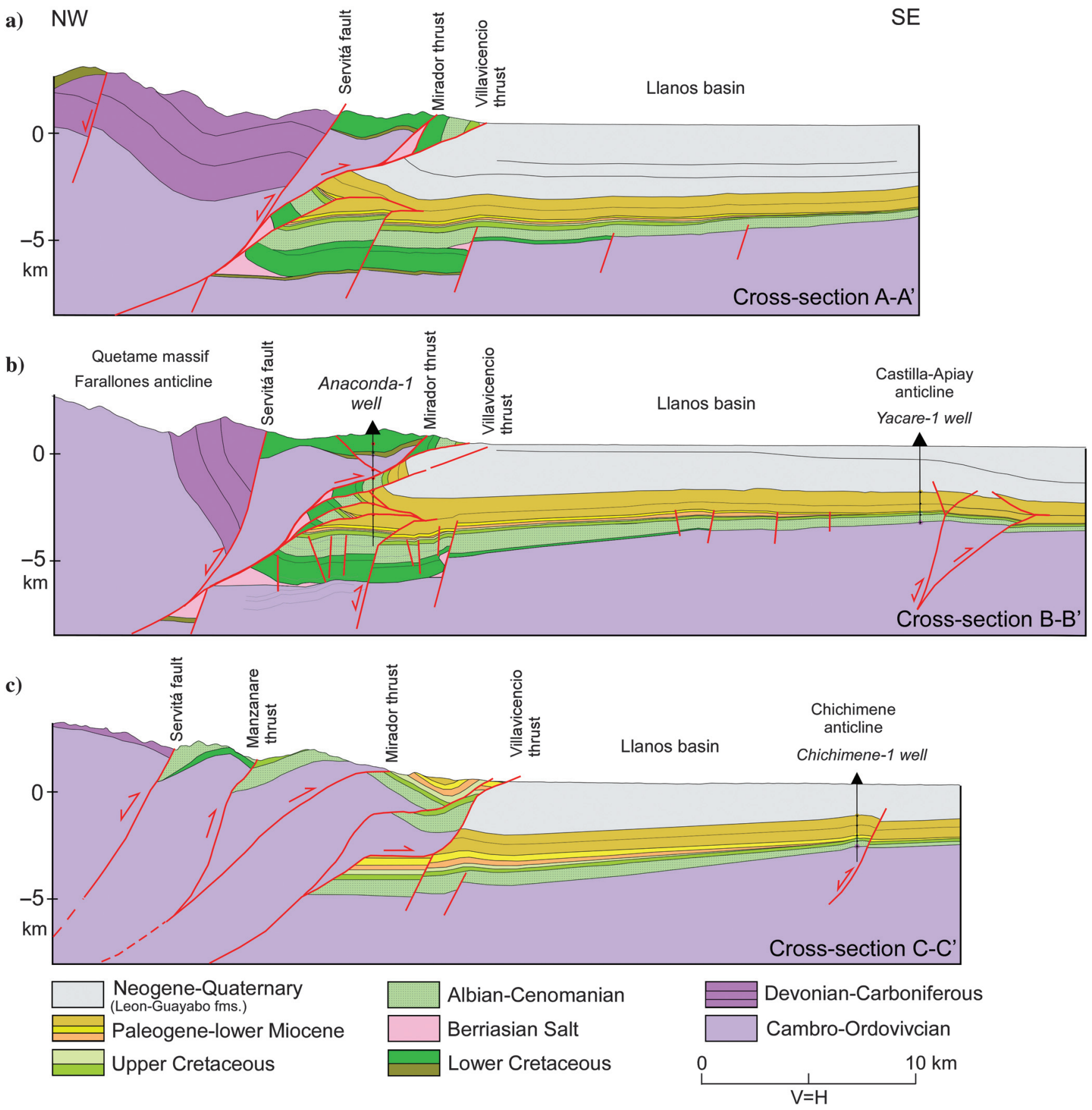

Figure 5. Cross sections A-A', B-B', and C-C' across the Guatiquía and Guamal segments of the EC foothills (see Figure 1 for location). Note the structural variation and the significant thickness change of the Cretaceous sequence from the north to south. Cross section B-B' (the Villavicencio section) is kinematically restored in Figure 7. 
overturned folds are not unique and alternatives include fault-propagation or trishear folding (e.g., Allmendinger, 1998), but on the basis of the indicators described above, we favor and will explore a model combining thrust faulting and diapirism.

\section{Kinematic modeling of the Villavicencio section}

Section B-B' (Villavicencio transect) was selected for kinematic modeling to illustrate our proposed model for the evolution of the Guatiquía foothills (Figure 7). The modeling includes extensional faulting, salt diapirism, and tectonic inversion. In the proposed model, the Cretaceous salt is assumed to start moving very early during the extensional episode (Figure 7f), as is common in salt-bearing basins (Jackson and Vendeville, 1994). Comparison of outcrop data and the Anaconda-1 well reveals marked thickness variations in the Lower Cretaceous across the Mirador and Servitá faults, which indicates former extensional faulting. In the hanging wall of the Mirador thrust, zircon (U-Th)/He ages are reset but zircon fission-track ages are not (Parra et al., 2009b; Jimenez et al., 2013), indicating that the basement of this unit was buried to reach temperatures between $180^{\circ} \mathrm{C}$ and $250^{\circ} \mathrm{C}$ from Cretaceous to recent times. In contrast, zircon fission tracks are reset in the hanging wall (HW) of the Servitá fault, which indicates a greater burial in this unit. According to our resto-

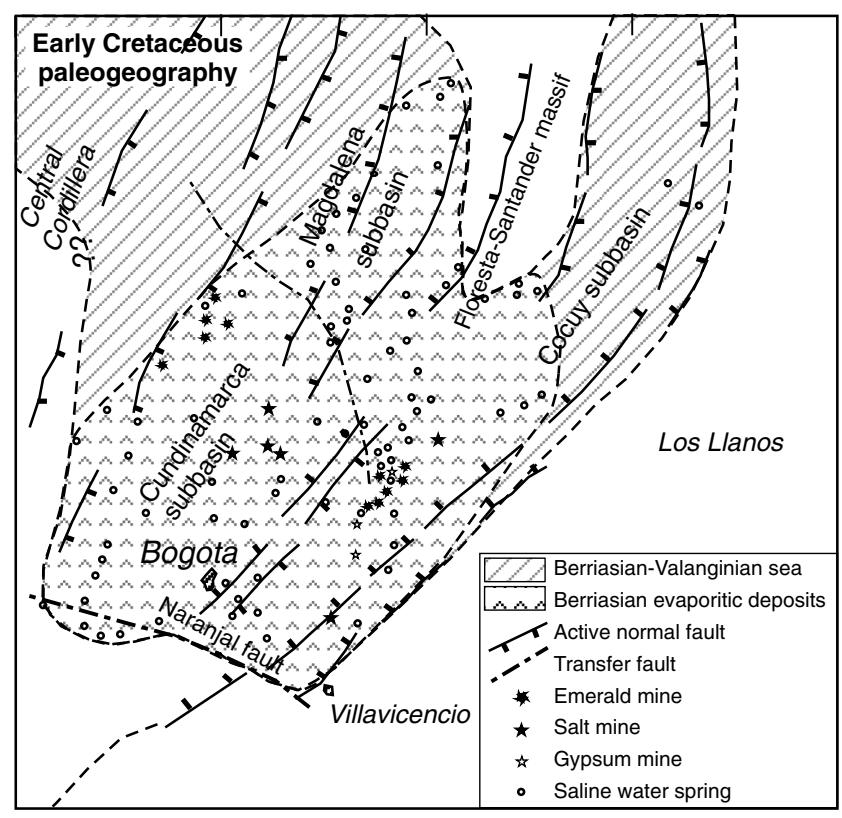

Figure 6. Paleogeographic reconstruction to early Cretaceous times, showing the extension of the BerriasianValanginian sea, the extent of the Berriasian evaporitic depositional system, and the main active tectonic structures (not restored for orogenic shortening). Also shown are the present-day location of emerald mines (on Berriasian-Valanginian layers), the Berriasian salt and gypsum mines, and saline springs (constructed on the basis of data from Etayo et al. (1969) and Sarmiento-Rojas et al. (2006). ration, the maximum burial depths were probably attained during Paleogene times (Figure 7e).

The Buenavista anticline may have originated as a salt wall associated with an extensional fault (Figure 7), later squeezed during the compression, so the salt formation has been largely removed. The early activity of salt, together with the extension, may have contributed to the change in thickness observed in the synrift sequences as described above. Salt continued to rise into structurally thinned zones during early Paleocene-Eocene times. The Anaconda-1 well found upper Eocene sediments unconformable over the Maastrichtian, potentially attesting for uplift in the salt wall (Figure 7e), and the Mirador Formation drilled by the well showed a very high formation of water salinity. Because this unit is attributed to fluvialshallow marine environments, the anomalous salinity may be ascribed to a diapir growing at the surface and being partially dissolved during early Eocene times. Alternatively, the structure may have been originated during the early Paleogene as an eroded, salt-cored detachment fold, although compressional deformation as old as that has never been recognized in the GuatiquíaGuamal foothills (Toro et al., 2004; Jimenez et al., 2013).

During the main Andean orogeny episode, extensional faults were reactivated and the Paleozoic basement uplifted (Figure 7), as occurs all along the cordillera (Mora et al., 2008). The squeezing of the diapir and the inversion of the Servitá fault are interpreted to be contemporaneous and attributed to the late Oligocene to early Miocene (Figure 7d), in agreement with the zircon fission tracks (ZFT) and zircon Helium (ZHE) ages that document an exhumation from approximately $180^{\circ} \mathrm{C}$ to $120^{\circ} \mathrm{C}$ from the mid Oligocene to the Pliocene (Jimenez et al., 2013). Mid-Oligocene cooling ages ( $29 \pm 2.3 \mathrm{Ma}$; Jimenez et al., 2013) indicate that the Andean exhumation commenced immediately after the maximum burial attained during the late Eocene-early Oligocene (Figure 7d and 7e). Subsequently, with the complete closure of the diapir stem by squeezing, it could no longer accommodate shortening, and this caused the initiation of new thrusts cross cutting the antiformal structure (Figure 7c). The basement-involved reactivation of the salt weld gave rise to the present Mirador thrust and a series of small imbrications in the inverted flank of the former diapir.

For the restoration of the imbricate thrusts that segment the steep flank of the old diapir in front of Mirador thrust, we assumed a break-back sequence of propagation (Figure $7 \mathrm{a}-7 \mathrm{c}$ ) on the basis of (1) the leading imbricate thrusts are fossilized under the molassic sediments and (2) in the restoration, the Mirador thrust, interpreted as the reactivation of the salt weld, was almost vertical prior to thrust imbrication of the steep flank of the diapir. Displacement on this imbricate sequence is attributed to late Miocene to recent times, in accordance with approximately 3-Ma apatite fission track ages (Mora et al., 2008). The Mirador thrust is the last to be formed within the system; late blind thrusting within the foreland basin, in which seismic data show involved 


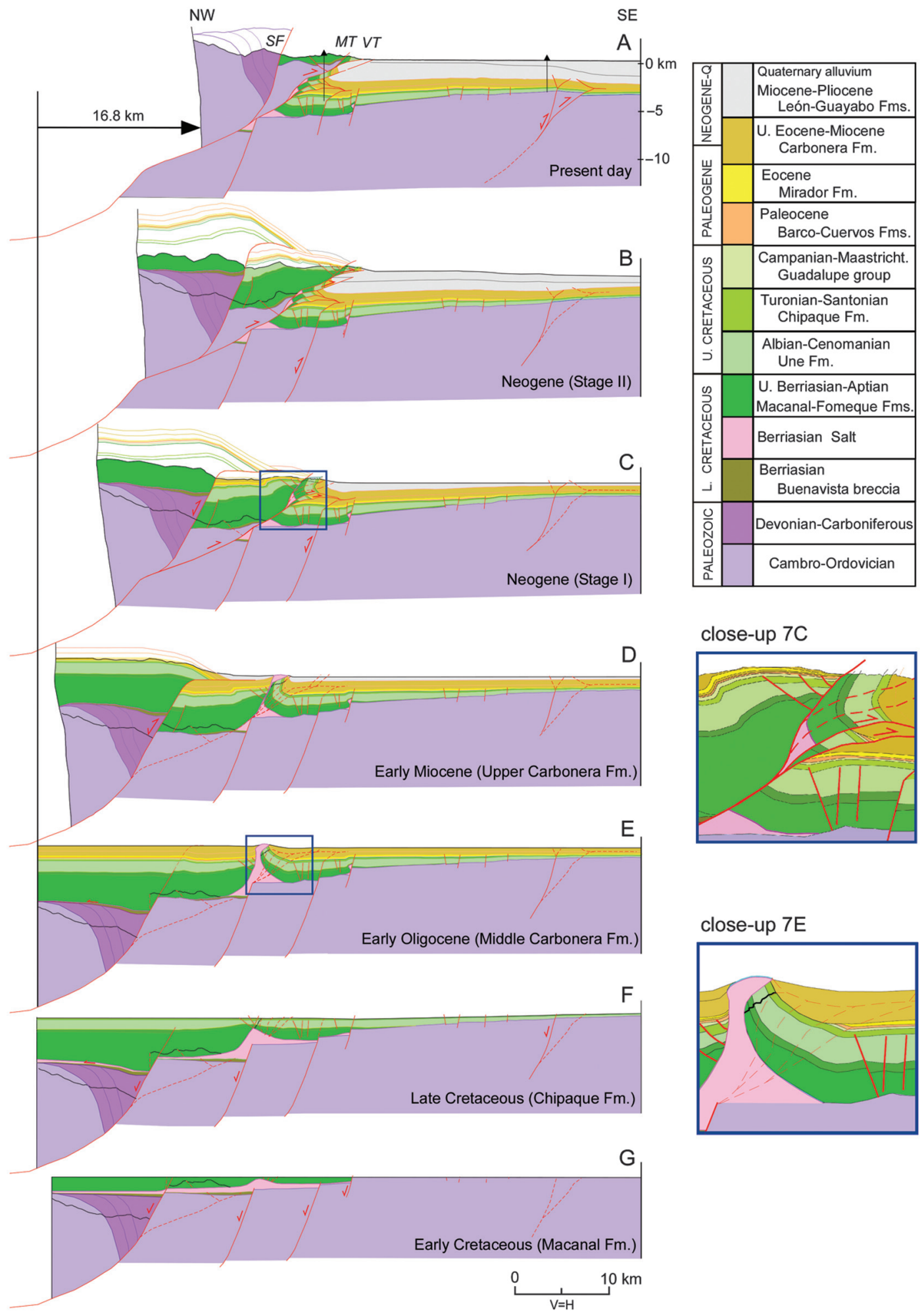

Figure 7. Kinematic restoration of the Villavicencio transect of the Guatiquía foothills (section B-B' in Figures 1 and 5). The section was restored to an initial state in early Cretaceous times. Restoration was made with 2DMove software using the algorithm fault-parallel flow for compressional faults, the algorithm inclined shear for extensional faults, and the algorithm flexural-slip unfolding for salt diapir unfolding. Each fault was moved back until the preslip stage, restoring the folds wherever necessary. See the text for discussion of each stage of the model. MF, Mirador thrust; SF, Servitá fault; VF, Villavicencio thrust. The final shortening along the section is of $16.8 \mathrm{~km}$ (23\%), assuming a conservative original width of the diapir of approximately $700 \mathrm{~m}$. 
the entire molassic sequence, is represented as contemporaneous (Figure 7a).

\section{Conclusions}

We suggest that the fault boundaries of the Mesozoic extensional basins as well as the mechanical behavior of the infill (in particular weak evaporites) played a major influence in the tectonic configuration of the foothills of the EC. Cross sections across the eastern foothills in the Guatiquía-Guamal segment highlight a lateral variability in which from the north to south, the structural style changes from thickskinned tectonic inversion and large-scale folding producing an anomalous overturned forelimb (Guatiquía area) to a simple thrust imbricate fan (Guamal area), via a transfer fault inherited from the Mesozoic extension.

The restoration of a regional transect through the Villavicencio area illustrates a complex kinematic evolution characterized by extensional, contractional, and salt tectonics. This area constituted the western and southern edge of the Cundinamarca extensional basin during the early Cretaceous. The area accumulated thick marine sediments including evaporitic layers that markedly influenced the entire history of deformation. The present-day Buenavista faulted anticline is interpreted as a former salt wall associated with the extensional Mirador fault, later squeezed during continuous shortening. The large overturned limb of the anticline is compatible with this process. In late shortening stages, welding of the diapir resulted in break-through thrusting across the overturned flap.

We proposed a previously unrecognized pattern of diapirism for the EC foothills. The new interpretation for the Guatiquía area leads to envisage that the known salt occurrences in the EC may be signs of a larger evaporitic depositional system, underestimated in previous interpretations, whose influence in terms of salt tectonics may cover wide parts of the EC of Colombia.

\section{Acknowledgments}

We thank the ICP-ECOPETROL at Bucaramanga for providing geologic maps and seismic profiles on which this study is based. Financial support was provided by the Spanish project CGL2010-15416. The software Move used in cross-section construction, and restoration was provided by Midland Valley through the ASI program. The reviews by M. Rowan, P. Kraemer, and the associate editor O. Ferrer substantially helped to improve the manuscript.

\section{References}

Allmendiger, R. W., 1998, Inverse and forward numerical modeling of trishear fault- propagation folds: Tectonics, 17, 640-656, doi: 10.1029/98TC01907.

Branquet, Y., A. Cheilletz, P. R. Cobbold, P. Baby, B. Laumonier, and G. Giuliani, 2002, Andean deformation and rift inversion, eastern edge of Cordillera Oriental (Guateque-Medina area), Colombia: Journal of South American Earth Sciences, 15, 391-407, doi: 10.1016/ S0895-9811(02)00063-9.

Cazier, E. C., A. B. Hayward, G. Espinosa, J. Velandia, J. F. Mugniot, and W. G. Leel Jr., 1995, Petroleum geology of the Cusiana Field, Llanos Basin foothills, Colombia: AAPG Bulletin, 79, 1444-1463.

Cheilletz, A., and G. Giuliani, 1996, The genesis of the Colombian emeralds: A restatement: Mineralium Deposita, 31, 359-364, doi: 10.1007/BF00189183.

Colletta, B., F. Hebrard, J. Letouzey, P. Werner, and J. L. Rudkiewicz, 1990, Tectonic style and crustal structure of the Eastern Cordillera (Colombia) from a balanced cross-section, in J. Letouzey, ed., Petroleum and tectonics in mobile belts: Editions Technip, 81-100.

Cooper, M. A., F. T. Addison, R. Álvarez, M. Coral, R. H. Graham, S. H. Hayward, J. Martínez, J. Naar, R. Peñas, A. J. Pulham, and A. Taborda, 1995, Basin development and tectonic history of the Llanos Basin, Eastern Cordillera, and Middle Magdalena Valley, Colombia: AAPG Bulletin, 79, 1421-1443.

Dengo, C. A., and M. C. Covey, 1993, Structure of the Eastern Cordillera of Colombia: Implications for trap styles and regional tectonics: AAPG Bulletin, 77, 1315-1337.

Dorado, J., 1990, Contribución al conocimiento de la estratigrafía de la Formación Brechas de Buenavista (límite Jurásico-Cretácico): Región Noroeste de Villavicencio (Meta): Geología Colombiana, 17, 7-40.

Etayo, F., G. Renzoni, and D. Barrero, 1969, Contornos sucesivos del mar Cretaceo en Colombia: I Congreso Colombiano de Geología, Memorias, 217-253.

Giuliani, G., A. Cheilletz, C. Arboleda, V. Carrillo, F. Rueda, and J. H. Baker, 1995, An evaporitic origin of the parent brines of Colombian emeralds: Fluid inclusion and sulphur isotopic evidence: European Journal of Mineralogy, 7, 151-166, doi: 10.1127/ejm/7/1/0151.

Gomez, E., T. E. Jordan, R. W. Allmendinger, and N. Cardozo, 2005, Development of the Colombian foreland-basin system as a consequence of diachronous exhumation of the northern Andes: Geological Society of America Bulletin, 117, 1272-1292, doi: 10.1130/ B25456.1.

Graham, R., M. Jackson, R. Pilcher, and B. Kilsdonk, 2012, Salt tectonics, sediments and prospectivity: Geological Society, London, Special Publications, 363, 595-615, doi: 10.1144/SP363.30.

Hoorn, C., J. Guerrero, G. A. Sarmiento, and M. A. Lorente, 1995, Andean tectonics as a cause for changing drainage patterns in Miocene northern South America: Geology, 23, 237-240, doi: 10.1130/0091-7613(1995)023<0237: ATAACF $>2.3 . \mathrm{CO} ; 2$.

Horton, B. K., J. E. Saylor, J. Nie, A. Mora, M. Parra, A. Reyes-Harker, and D. F. Stockli, 2010, Linking sedimentation in the northern Andes to basement configuration, Mesozoic extension, and Cenozoic shortening: Evidence from detrital zircon U-Pb ages, Eastern Cordillera, 
Colombia: Geological Society of America Bulletin, 122, 1423-1442, doi: 10.1130/B30118.1.

Hubach, E., 1957, Contribución a las unidades estratigráficas de Colombia: Servicio Geológico Nacional, Bogotá, Informe, 1212, 1-166.

Jackson, M. P. A., and B. C. Vendeville, 1994,. Regional extension as a geologic trigger for diapirism: Geological Society of America Bulletin, 106, 57-73, doi: 10.1130/ 0016-7606(1994)106<0057:REAAGT>2.3.CO;2.

Jimenez, L., A. Mora, W. Casallas, A. Silva, E. Tesón, J. Tamara, J. Namson, I. C. Higuera-Diaz, A. Lasso, and D. F. Stockli, 2013, Segmentation and growth of foothills thrust-belts adjacent to inverted grabens: The case of the Colombian Llanos foothills: Geological Society, London, Special Publications, 377, 189-220, doi: 10 .1144/SP377.11.

Kammer, A., A. Velásquez, and J. P. Duran, 2005, The deformation front in the Llanos foothills of the Eastern Cordillera of Colombia: Interaction between thickand thin-skinned tectonics at a segmented boundary: Presented at 6th International Symposium on Andean Geodynamics, Extended Abstracts, 417-419.

Kluth, C., R. Ladd, M. De Aras, L. Gomez, and N. Tilander, 1997, Different structural styles and histories of the Colombian foreland basin, Castilla and Chichimene oil field areas, east-central Colombia: VI Simposio Bolivariano de Exploracion Petrolera en las Cuencas Subandinas, Asociación Colombiana de Geólogos y Geofísicos del Petróleo, Abstracts, 185-197.

Martinez, J. A., 2006, Structural evolution of the Llanos foothills, EasternCordillera, Colombia: Journal of South American Earth Sciences, 21, 510-520, doi: 10.1016/j .jsames.2006.07.010.

McLaughlin, D. H., 1972, Evaporite deposits of Bogota Area, Cordillera Oriental, Colombia: AAPG Bulletin, 56, 2240 2259.

Mora, A., T. Gaona, J. Kley, D. Montoya, M. Parra, L. I. Quiroz, G. Reyes, and M. R. Strecker, 2009, The role of inherited extensional fault segmentation and linkage in contractional orogenesis: A reconstruction of Lower Cretaceous inverted rift basins in the Eastern Cordillera of Colombia: Basin Research, 21, 111-137, doi: 10.1111/j .1365-2117.2008.00367.x.

Mora, A., and M. Parra, 2008, The structural style of footwall shortcuts along the eastern foothills of the Colombian Eastern Cordillera. Differences with other inversion related structures: Ciencia, Tecnología y Futuro, 3, 7-21.

Mora, A., M. Parra, M. R. Strecker, A. Kammer, C. Dimaté, and F. Rodríguez, 2006, Cenozoic contractional reactivation of Mesozoic extensional structures in the Eastern Cordillera of Colombia: Tectonics, 25, TC2010, doi: 10 .1029/2005TC001854.

Mora, A., M. Parra, M. R. Strecker, E. R. Sobel, H. Hooghiemstra, V. Torres, and J. Vallejo-Jaramillo, 2008, Climatic forcing of asymmetric orogenic evolution in the
Eastern Cordillera of Colombia: Geological Society of America Bulletin, 120, 930-949, doi: 10.1130/B26186.1.

Mora, A., M. Parra, M. R. Strecker, E. R. Sobel, G. Zeilinger, C. Jaramillo, S. Ferreira Da Silva, and M. Blanco, 2010, The eastern foothills of the Eastern Cordillera of Colombia: An example of multiple factors controlling structural styles and active tectonics: Geological Society of America Bulletin, 122, 1846-1864, doi: 10.1130/ B30033.1.

Mora, A., A. Reyes, G. Rodriguez, E. Tesón, J. C. Ramirez, M. Parra, V. Caballero, J. P. Mora, I. Quintero, V. Valencia, M. Ibañez, B. K. Horton, and D. F. Stockli, 2013, Inversion tectonics under increasing rates of shortening and sedimentation: Cenozoic example from the Eastern Cordillera of Colombia: Geological Society, London, Special Publications, 377, 411-442, doi: 10 .1144/SP377.6.

Parra, M., A. Mora, C. Jaramillo, M. R. Strecker, E. R. Sobel, L. I. Quiroz, M. Rueda, and V. Torres, 2009a, Orogenic wedge advance in the northern Andes: Evidence from the Oligocene-Miocene sedimentary record of the Medina Basin, Eastern Cordillera, Colombia: Geological Society of America Bulletin, 121, 780-800, doi: 10 $.1130 / \mathrm{B} 26257.1$.

Parra, M., A. Mora, E. R. Sobel, M. R. Strecker, and R. González, 2009b, Episodic orogenic front migration in the northern Andes: Constraints from low-temperature thermochronology in the Eastern Cordillera, Colombia: Tectonics, 28, TC4004, doi: 10.1029/2008TC002423.

Pulido, O., L. S. Gómez, and P. Marín, 1998, Geologia de la Plancha 266 Villavicencio, scale 1:100.000: Ingeominas, 1 plate.

Renzoni, G., 1968, Geología del Macizo de Quetame: Geología Colombiana, 5, 75-127.

Rowan, M. G., K. A. Giles, T. E. Hearon, IV, C. E. Gannaway, and J. C. Fiduk, 2014, Megaflaps along the edges of steep diapirs and beneath salt sheets: Models and examples: Presented at 2014 International Conference \& Exhibition, AAPG, 90194.

Rowan, M. G., and R. Linares, 2000, Fold-evolution matrices and axial-surface analysis of fault-bend folds: Application to the Medina anticline, Eastern Cordillera, Colombia: AAPG Bulletin, 84, 741-764.

Sarmiento-Rojas, L. F., 2001, Mesozoic rifting and Cenozoic Basin inversion history of the Eastern Cordillera, Colombian Andes: Inferences from tectonic models: Ph.D. thesis, Vrije Universiteit.

Sarmiento-Rojas, L. F., J. D. Van Wess, and S. Cloetingh, 2006, Mesozoic transtensional basin history of the Eastern Cordillera, Colombian Andes: Inferences from tectonic models: Journal of South American Earth Sciences, 21, 383-411, doi: 10.1016/j.jsames.2006.07.003.

Teixell, A., E. Tesón, J.-C. Ruiz, and A. Mora, 2015, The structure of an inverted back-arc rift: Insights from a transect across the Eastern Cordillera of Colombia near Bogotá, in C. Bartolini, and P. Mann, eds., Petroleum 
geology and hydrocarbon potential of Colombia Caribbean Margin: AAPG Memoir 108.

Tesón, E., A. Mora, A. Silva, J. Namson, A. Teixell, J. Castellanos, W. Casallas, M. Julivert, M. Taylor, M. A. Ibáñez-Mejía, and V. A. Valencia, 2013, Thick-skin-dominated Orogens: From initial inversion to full accretion: Geological society, London, Special Publications, 377, 257-283, doi: 10.1144/SP377.10.

Toro, J., F. Roure, N. Bordas-Le Floch, S. Le Cornec-Lance, and W. Sassi, 2004, Thermal and kinematic evolution of the Eastern Cordillera fold-and-thrust belt, Colombia, in R. Swennen, F. Roure, and J. W. Granath, eds., Deformation, fluid flow, and reservoir appraisal in Foreland fold and thrust belts: AAPG, Hedberg Series 1, 79-115.

Wokittel, R., 1960, Recursos minerales de Colombia: Servicio Geológico Nacional, Bogotá, Official Compilation of Geological Studies 10.

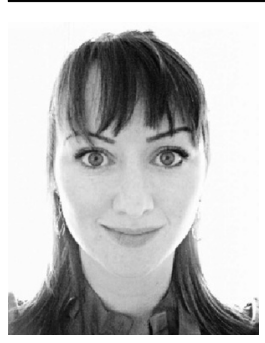

Vanessa Parravano received a B.S. (2005) in geological engineering from the Universidad de los Andes at Venezuela, an M.S. in geophysics from the Universitat de Barcelona, and an M.S. in reservoir geology from the Universitat Autònoma de Barcelona. In 2006, she joined the Petróleos de Venezuela (PDVSA) exploration group as a seismic interpreter/structural geologist focused in regional studies in Venezuelan basins. In 2014, she joined SGS Horizon as a geophysicist, where she performed exploration and production projects in Italy, West Africa, and the North Sea. In 2015, she joined the Petrogas N.L. exploration team as a seismic interpreter focused on prospects evaluation in the North Sea. Her research interests include structural geol- ogy, kinematics of deformation, structural and tectonic controls on petroleum systems, and basin analysis.

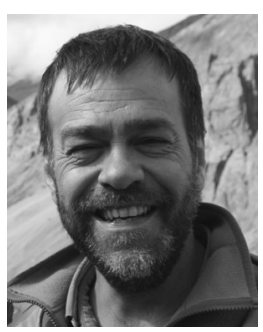

Antonio Teixell received a license degree (1984) in geology from the Universitat de Barcelona and Ph.D. (1992). He is a professor and head of the department of geology at the Universitat Autònoma de Barcelona. He worked for the Geological Survey of Spain and performed research as a visiting student or scholar at the State University of New York-Albany and the University of Texas-Austin. He joined the Universitat Autònoma de Barcelona in 1993. His research interests include the geology and geophysics of fold and thrust belts and foreland basins, with an emphasis on the relationships among tectonics, sedimentation, and the evolution of relief. Areas where he is currently involved in multidisciplinary studies include the mountain belts and basins of the Pyrenees, the Atlas, and the Northern Andes.

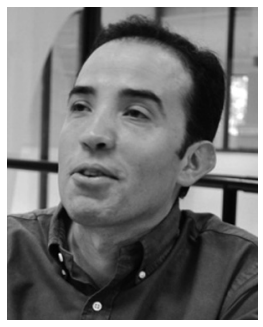

Andrés Mora received a B.S. in geology from the Universidad Nacional de Colombia and a Ph.D. from the Institut für Geowissenschaften, Universität Potsdam, Germany. $\mathrm{He}$ is a senior researcher and former leader of the Cronología de la Deformación en las Cuencas Subandinas (20082011) research project at EcopetrolInstituto Colombiano del Petróleo. Now he is in charge of the Geological Modeling research area at EcopetrolICP. His research interests include structural geology, petroleum geology, and basin analysis. 